\title{
ANTIOXIDANT CAPACITY OF PEQUI (Caryocar brasiliense Camb.) PULP IS PRESERVED BY FREEZE-DRYING AND LIGHT-RESISTANT PACKAGING ${ }^{1}$
}

\author{
NARA RÚBIA RODRIGUES DO NASCIMENTO², ALINE MEDEIROS ALVES ${ }^{3}$, \\ MARA REIS SILVA ${ }^{4}$, MARIA MARGARETH VELOSO NAVES ${ }^{5}$
}

ABSTRACT - Pequi (Caryocar brasiliense Camb.) pulp is rich in bioactive compounds. However, seasonality and perishability limit its availability in the market. This work aimed to determine the physicochemical characteristics, including phenolic compounds and carotenoid concentrations, as well as the antioxidant capacity of lyophilized pequi pulp during storage in various packaging materials for 180 days. Pequi fruits were pulped, ground, freeze-dried and then vacuum packaged in transparent polyethylene (TP), polyethylene coated by aluminum foil (PA) and laminated foil (LA), respectively. The samples were stored under controlled temperature, humidity and luminosity. Proximate composition, phenolic compounds and carotenoids concentrations, and antioxidant capacity (DPPH• assay) were determined at the beginning of the study and the end of each month, during 180 days. Lyophilized pequi pulp had 48.87, 6.17, and $4.20 \mathrm{~g} .100 \mathrm{~g}^{-1}$ lipids, proteins, and total dietary fiber, respectively, and $556.79 \mathrm{kcal} .100 \mathrm{~g}^{-1}$ energy. PA and LA had similar effects against light-induced carotenoid oxidation. Negative correlations between the phenolic compound concentration and storage period, and antioxidant capacity and storage period; and a positive correlation between antioxidant capacity and phenolic compound content were observed. Light-resistant packaging decreased the carotenoid loss. Among the packaging, LA preserved the phenolic compounds and antioxidant capacity most effectively.

Index terms: antioxidants, carotenoids, Caryocar brasiliense, Cerrado, pequi.

\section{LIOFILIZAÇÃO E EMBALAGENS PROTEGIDAS DA LUZ PRESERVAM A CAPACIDADE ANTIOXIDANTE DA POLPA DE PEQUI (Caryocar brasiliense Camb.)}

RESUMO -A polpa de pequi apresenta quantidade elevada de compostos bioativos, contudo, sua sazonalidade e alta perecibilidade limitam sua disponibilidade no mercado. Este trabalho foi desenvolvido com o objetivo de determinar as características físico-químicas, o conteúdo de compostos fenólicos e de carotenoides, e a capacidade antioxidante da polpa liofilizada de pequi, e avaliar sua estabilidade durante 180 dias de armazenamento, em diferentes embalagens. Os frutos de pequi foram despolpados, e a polpa foi triturada, liofilizada e acondicionada a vácuo em três embalagens diferentes: polietileno transparente, polietileno revestida com papel alumínio e laminada (bopp metalizado com pet). As amostras foram armazenadas em condições controladas de temperatura, umidade e luminosidade. Foram determinadas a composição centesimal, os teores de compostos fenólicos e carotenoides e a capacidade antioxidante (DPPH•), no início do estudo e ao final de cada mês, por 180 dias. A polpa liofilizada de pequi apresentou 48,87 g.100g-1 de lipídios; 6,17 g.100g-1 de proteína; 4,20 g.100g-1 de fibra alimentar total, e valor energético de $556,79 \mathrm{kcal} .100 \mathrm{~g}-1$. A proteção à oxidação dos carotenoides pela ação da luz foi igualmente eficaz com o uso da embalagem de polietileno revestida com papel alumínio e da embalagem laminada. Observou-se correlação negativa entre concentração de compostos fenólicos e tempo de armazenamento, e capacidade antioxidante e o tempo de armazenamento; e positiva entre capacidade antioxidante e compostos fenólicos. As embalagens protegidas da luz reduziram a perda de carotenoides. A embalagem laminada se destacou por melhor preservar os compostos fenólicos e a capacidade antioxidante.

Termos para indexação: antioxidantes: Caryocar brasiliense, carotenoides, Cerrado, pequi.

\footnotetext{
${ }^{1}$ (Paper 188-15). Received July, 31 2015. Accepted August 15, 2016.

${ }^{2}$ Master Student, School of Nutrition, Federal University of Goiás (UFG), Goiânia-GO, Brazil . E-mail: nara.n.nutri@gmail.com ${ }^{3}$ Master in Food Science and Technology, Nutritionist of School of Nutrition, UFG. Goiânia-GO. E-mail: amedeiros87@gmail.com ${ }^{4} \mathrm{PhD}$ in Food and Nutrition, Professor of School of Nutrition, UFG.Goiânia-GO. E-mail: mararsilva@gmail.com ${ }^{5} \mathrm{PhD}$ in Food Science, Professor of School of Nutrition, UFG.Goiânia-GO. E-mail: mmvnaves@gmail.com
} 


\section{INTRODUCTION}

Pequi (Caryocar brasiliense Camb.) is a native fruit of the Cerrado region (Brazil) that has a high potential for commercialization and use in the food industry, with valuable nutritional and bioactive properties (PINTO et al., 2016). Pequi pulp is rich in lipids, dietary fiber, carotenoids and phenolic compounds (CORDEIRO et al., 2013; RIBEIRO et al., 2014). According to in vivo studies, the consumption of pequi pulp oil can improve the antioxidant defense system (COLOMBO et al., 2015) and shows hypolipidemic effects, decreasing oxidative stress and inflammatory processes (FIGUEIREDO et al., 2016).

Pequi pulp undergoes rapid postharvest decay due to its high moisture content and water activity, a high respiration rate and ethylene production, which limit its shelf life and market availability (OLIVEIRA et al., 2010; RODRIGUES et al., 2009). The freeze-drying or lyophilization process involves drying the sample under vacuum at low temperature (sublimation). Thus, besides decreasing the moisture and water activity, freeze-drying can preserve the structural and chemical integrity/composition of foods (OLIVEIRA et al., 2016). The use of lightresistant packaging represents another strategy that may decrease the loss of bioactive compounds from the food during storage. Moreover, when the product is vacuum packaged, the oxygen concentration is decreased, decreasing the growth of aerobic bacteria, as well as preserving antioxidant substances (SELCUK; ERKAN, 2015).

In this context, lyophilization of pequi pulp may enhance its storage stability, benefiting the food industry. This study aimed to determine the physicochemical characteristics, contents of phenolic compounds and carotenoids, and antioxidant capacity of freeze-dried pequi pulp, and to evaluate the influence of various packaging materials on the stability of its bioactive compounds during 180 days of storage.

\section{MATERIAL AND METHODS}

\section{Fruit purchase and sample processing}

The pequi fruits were native to São Miguel do Araguaia, Goiás State, Brazil, and purchased from Goiás Supply Center (Central de Abastecimento de Goiás S.A., CEASA-GO). The fruits were selected based on size, color, ripeness stage and with uniform texture and no injuries. The fruits were first sanitized, and the pulp was extracted manually, then packaged in polyethylene bags, frozen at $-80{ }^{\circ} \mathrm{C}$, crushed in a multiprocessor and freeze-dried (L108, Liotop). After, the ground pulp was vacuum packaged in three types of packages: transparent polyethylene (TP), polyethylene coated by aluminum foil (PA) and laminated foil (LA: metallized biaxially oriented polypropylene (-BOPP) with polyethylene terephthalate (PET)), respectively. The samples were stored at controlled temperature $\left(22 \pm 2{ }^{\circ} \mathrm{C}\right)$, humidity (relative humidity $=60 \pm 5 \%$ ) and light (light-dark cycle of $12 \mathrm{~h}$ ) for up to 180 days.

\section{Physicochemical and microbiological analyses}

Lyophilized pequi pulp (LPP) was used for the following analyses, performed in triplicate: titratable acidity, measured by titration with sodium hydroxide solution $\left(0.1\right.$ mol. $\left.\mathrm{L}^{-1}\right) ; \mathrm{pH}$, estimated electrometrically, with $10 \mathrm{~g}$ of diluted sample in $100 \mathrm{~mL}$ of ultrapure water after agitation (AOAC, 2010); and color parameters ( $\left.L^{*}, a *, b *\right)$, with a colorimeter (Quest II Sphere, Hunter Lab, Reston, VA, USA), including calculation of hue angle $\left(\mathrm{h}^{\circ}\right)$ and chroma $\left(\mathrm{C}^{*}\right)$, according to McGuire (1992).

The proximate composition was determined according to the following analyses: moisture; total nitrogen by micro-Kjeldahl and conversion to crude protein using the factor 6.25 (AOAC, 2010); total lipids (BLIGH; DYER, 1959); ash; and total dietary fiber, both the insoluble and soluble fractions (AOAC, 2010). The total carbohydrate content was estimated by difference, subtracting from 100 the values obtained for moisture, protein, lipids, ash and total dietary fiber. The total energy was obtained using the Atwater factors of 4, 4 and 9 kcal.g-1 for protein, carbohydrates and lipids, respectively (MERRIL; WATT, 1973).

Microbiological analyses for the presence of Salmonella and coliforms (at $45^{\circ} \mathrm{C}$ ) were performed at zero, 90 and 180 days of storage, according to the RDC $\mathrm{n}^{\circ} 12$ (BRAZIL, 2001), and the American Public Health Association (2001) method.

\section{Sample extracts and analysis of total phenolic compounds}

Sample extracts were prepared according to Prior et al. (2003). Aliquots of LPP (0.05 g) were homogenized with $375 \mu \mathrm{L}$ of ethanol and $375 \mu \mathrm{L}$ of ultrapure water for $30 \mathrm{~s}$, and then $750 \mu \mathrm{L}$ of hexane was added. The solution was stirred for $30 \mathrm{~s}$ and centrifuged (MPW 350-R, MPW Med Instruments, Warsaw, Poland) at $2,320 \mathrm{x}$ g for $5 \mathrm{~min}$ at $18{ }^{\circ} \mathrm{C}$. A 
solution with $750 \mu \mathrm{L}$ of acetone/ultrapure water/ acetic acid (70:29.5:0.5) was added to the residue, which was then homogenized in an ultrasonic bath at $37^{\circ} \mathrm{C}$ for 5 min with stirring. The extract was kept at room temperature for $10 \mathrm{~min}$ and then shaken for 10 s. After, it was centrifuged at $7,516 \mathrm{xg}$ and $18{ }^{\circ} \mathrm{C}$ for $10 \mathrm{~min}$. The supernatant was removed and transferred to a $10 \mathrm{~mL}$ volumetric flask. This extract was used for total phenolic compounds and antioxidant capacity analyses. These analyses were performed at baseline and every 30 days during 180 days of storage.

The method described by Genovese et al. (2008) was used to measure the total phenolic compounds. A $0.25 \mathrm{~mL}$ aliquot of the extract was homogenized with $0.25 \mathrm{~mL}$ of Folin-Ciocalteu reagent and $2.0 \mathrm{~mL}$ of ultrapure water. After $3 \mathrm{~min}$ at room temperature, $0.25 \mathrm{~mL}$ saturated sodium carbonate solution was added, and the mixture placed at $37{ }^{\circ} \mathrm{C}$ in a water bath for $30 \mathrm{~min}$. The absorbance was measured at $750 \mathrm{~nm}$ in a UV/visible spectrophotometer (V-630, Jasco). Results were expressed as mg of gallic acid equivalent (GAE) per $100 \mathrm{~g}$ of lyophilized sample.

\section{Total carotenoids analysis}

The carotenoids were extracted using the method described by Rodriguez-Amaya (2001). All steps were carried out in a controlled temperature environment, dim light and with the addition of butylated hydroxytoluene (BHT). Samples of LPP $(1.0 \mathrm{~g})$ were homogenized with cold acetone, and vacuum filtrated for three consecutive times. The extract obtained was repeatedly vacuum filtered until the residue became colorless. The residue was washed three consecutive times in a separation funnel containing hexane and distilled water, for complete removal of acetone. The fraction with hexane was stored in a volumetric flask and the volume adjusted to $100 \mathrm{~mL}$ with hexane. Then, absorbance was measured from 350 to $700 \mathrm{~nm}$ in a spectrophotometer. The highest absorbance value was used to calculate the total carotenoid contents.

\section{Diphenyl-1-picrylhydrazyl (DPPH•) assay}

The DPPH• radical sequestration method was performed as described by Brand-Williams et al. (1995). A $0.1 \mathrm{~mL}$ aliquot of the extract was transferred to an amber vial, and then $3.9 \mathrm{~mL}$ of $0.0025 \%$ DPPH• solution added. The mixture was then vortexed for $10 \mathrm{~s}$, and after $120 \mathrm{~min}$, the absorbance was measured at $515 \mathrm{~nm}$. The results were expressed as $\mu \mathrm{mol}$ of Trolox equivalents (TE) per $\mathrm{g}$ of lyophilized sample.

\section{Statistical analysis}

The results were expressed as mean \pm standard deviation. The mean values were compared by Tukey's test at $5 \%$ probability. Pearson's correlation coefficients were calculated for the phenolic compounds, carotenoids, antioxidant capacity and storage period for each type of package tested. Statistical data have been computed using Statistica 7.0.

\section{RESULTS AND DISCUSSION}

LPP showed an $\mathrm{L}^{*}$ and $\mathrm{h}^{\circ}$ angle (Table 1) close to the color parameters reported by Cordeiro et al. (2013), for pequi pulps from four regions of Mato Grosso State (Brazil), which ranged between 48.65-60.08 for L*, and between 63.23-69.38 for $\mathrm{h}^{\mathrm{o}}$. The $\mathrm{L}^{*}$ and $\mathrm{h}^{\mathrm{o}}$ parameters represent the brightness and the hue of the sample, respectively. The other parameters showed lower values than those reported in the study mentioned above, which were $37.27-$ 41.86 for $\mathrm{a}^{*}, 83.63-98.96$ for $\mathrm{b}^{*}$ and $93.65-106.06$ for $C^{*}$. Thereby, fruits examined in this study had less intense red and yellow color than those studied by Cordeiro et al. (2013).

LPP had a total acidity (Table 1) higher than that reported for pequi from Parana State, of $0.04 \%$ (ARÉVALO-PINEDO et al., 2010) and Minas Gerais State, of $0.7 \%$ (PAZ et al., 2014). However, the LPP has acidity lower than that of many other native fruit pulps, such as lyophilized cajá pulp at 9.11\% (OLIVEIRA et al., 2014). Fruits with low acidity are preferred for in natura consumption. LPP's pH (Table 1) was close to that reported by Arévalo-Pinedo et al. (2010), of pH 7.36, and Paz et al. (2014), of $\mathrm{pH} 7.00$, for pequi pulp, but higher than that reported for other native fruit pulps, such as sapoti, at pH 5.58 (OLIVEIRA et al., 2011), and cajá, at pH 2.65 (OLIVEIRA et al., 2014). The titratable acidity and $\mathrm{pH}$ parameters are important for product standardization and to monitor changes during processing and storage (SELANI et al., 2016).

The LPP moisture content (Table 1) was close to that observed for lyophilized sapoti pulp, of $12.30 \%$ (OLIVEIRA et al., 2011), but higher than that reported for lyophilized cajá pulp, of $2.05 \%$ (OLIVEIRA et al., 2014). The lyophilizationinduced moisture decrease contributes to preserving the product better and diversify its use. LPP is rich in lipids and energy (calories) compared to freezedried açaí pulp, which contains $40.75 \mathrm{~g} .100 \mathrm{~g}^{-1}$ lipids (MENEZES et al., 2008). Moreover, pequi pulp oil 
has a healthy fatty acids profile, with a predominance of monounsaturated fatty acids (CORDEIRO et al., 2013). The ash and protein contents were lower than those observed for freeze-dried açaí pulp, of 3.68 and $8.13 \mathrm{~g} .100 \mathrm{~g}^{-1}$, respectively (MENEZES et al., 2008).

Microbiological analysis of LPP indicated no Salmonella, and coliform counts at $45{ }^{\circ} \mathrm{C}$ were below the minimum value $\left(10^{2} \mathrm{CFU}_{\mathrm{g}} \mathrm{g}^{-1}\right)$ established by current Brazilian legislation (BRAZIL, 2001). In this context, the product was suitable for analysis during storage (Table 2).

The content of phenolic compounds in LPP

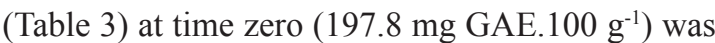
higher than that reported for lyophilized pulp of domesticated fruits, such as apple, at $68 \mathrm{mg}$ GAE. 100 $\mathrm{g}^{-1}$ (LEONTOWICZ et al., 2007), and guava, at 88.7 mg GAE. $100 \mathrm{~g}^{-1}$ (NUNES et al., 2016). At 180 days of storage, the total phenolic compounds in of LPP packaged in the TP and PA had decreased, but no significant decrease occurred when LPP was packaged in LA (Table 3). The loss of phenolic compounds may be the result of polyphenol oxidation and polymerization reactions, which decrease the number of free hydroxyl groups quantified by FolinCiocalteu assay (KLOPOTEK et al., 2005).

The total carotenoids content of LPP at time zero $\left(601.4 \mu \mathrm{g} . \mathrm{g}^{-1}\right)$, was much higher than that reported for freeze-dried mango $\left(51.7 \mu \mathrm{g} . \mathrm{g}^{-1}\right)$ (SOGI et al., 2015). The total carotenoids detected in the LA and PA packaged pulp was greater when compared with the TP packaged pulp at 180 days of storage (Table 3). The sensitivity of the carotenoids to light, temperature and oxidation reactions may explain the loss of these compounds during storage and the differences between the carotenoid contents of the pulps regarding the packaging material.

The DPPH• antioxidant capacity of LPP at zero time $\left(12.0 \mu \mathrm{mol} \mathrm{TE.} \mathrm{g}^{-1}\right)$ was close to that of a Chinese citrus fruit (Citrus reticulata) lyophilized pulp, of $14.17 \mu \mathrm{mol} \mathrm{TE} . \mathrm{g}^{-1}$ (XI et al., 2014). Antioxidant capacity decreased during the 180 days of storage. At the end of the study, there was no significant difference between the LPP antioxidant capacity stored in TP and PA, but both showed antioxidant capacity lower than that of LPP stored in LA (Table 3). Therefore, LA better preserved the phenolic compounds and carotenoids, as well as the antioxidant capacity of pequi pulp. A similar result was observed by Hymavathi and Khader (2005), who analyzed the stability of ascorbic acid, carotenoids and $\beta$-carotene of dehydrated mango pulp during storage in two different packages (LA and TP) for 180 days.

Pearson's correlation coefficients (Figure 1) showed a strong correlation between the total phenolic compounds and storage period of LPP packaged in TP and PA, and between antioxidant capacity and storage period of LPP packaged in TP, PA and LA. Thus, the phenolic compounds and antioxidant capacity gradually decreased during the storage period. However, there was less decrease in the phenolic compounds of LPP stored in LA, indicating that this package provided better protection against the gradual loss of phenolic compounds over time. There was a weak correlation between the total carotenoid contents and storage period for all packages studied.

Information about the effect of time on the content of phenolic compounds, carotenoids and antioxidant capacity in foods using different packages are important to determine the processing and marketing conditions required to maintain the integrity of the product. A linear regression model of the variables behavior (Figure 1) was done as previously reported in the literature for color parameters, total lipid and carotenoid content in pequi pulp (RIBEIRO et al., 2014).

A significant correlation was found between the antioxidant capacity and the total phenolic compounds in LPP packed in TP and PA (Table 4). Mokrani et al. (2016) observed a similar result, finding a strong correlation between $\mathrm{DPPH}$ antioxidant capacity and phenolic compounds in freeze-dried peach pulp $(\mathrm{r}=0.98)$. In contrast, no correlation between the antioxidant capacity and total carotenoid contents of LPP was observed, regardless of the package used for storage. This result suggests that the $\mathrm{DPPH} \cdot$ antioxidant capacity was more influenced by the content of phenolic compounds than carotenoids in LPP. 
TABLE 1 - Physicochemical characteristics, proximate composition and energy content of lyophilized pequi pulp (LPP).

\begin{tabular}{lc}
\hline Parameters & LPP \\
Color & $43.75 \pm 1.06$ \\
$\mathrm{~L}^{*}$ & $11.72 \pm 0.09$ \\
$\mathrm{a}^{*}$ & $17.19 \pm 2.22$ \\
$\mathrm{~b}^{*}$ & $64.55 \pm 2.46$ \\
$\mathrm{~h}^{\circ}$ & $20.82 \pm 1.85$ \\
$\mathrm{C}^{*}$ & $7.22 \pm 0.02$ \\
pH & $1.68 \pm 0.05$ \\
Acidity $(\%)$ & \\
Proximate composition $\left(\mathrm{g} .100 \mathrm{~g}^{-1}\right)$ & $11.65 \pm 0.30$ \\
Moisture & $1.84 \pm 0.03$ \\
Ash & $6.17 \pm 0.03$ \\
Protein & $48.87 \pm 0.51$ \\
Lipid & $4.20 \pm 0.00$ \\
Total dietary fiber & $2.70 \pm 0.07$ \\
$\quad$ insoluble & $1.55 \pm 0.07$ \\
$\quad$ soluble & $23.07 \pm 0.75$ \\
Carbohydrate & $556.79 \pm 2.14$ \\
Energy (kcal.100 g $\left.{ }^{-1}\right)$ &
\end{tabular}

${ }^{1}$ Mean \pm standard deviation of triplicate analyses.

TABLE 2 - Microbiological analysis of lyophilized pequi pulp (LPP) stored in various packages at 0, 90 and 180 days.

\begin{tabular}{clccc}
\hline \multirow{2}{*}{ Packages $^{1}$} & \multicolumn{1}{c}{ Microorganism } & \multicolumn{3}{c}{ Time (days) } \\
\cline { 3 - 5 } & & 0 & 90 & 180 \\
\hline \multirow{2}{*}{ TP } & Salmonella & $\mathrm{ND}$ & $\mathrm{ND}$ & $\mathrm{ND}$ \\
& Coliforms at $45^{\circ} \mathrm{C}$ & $<10^{2} \mathrm{CFU} / \mathrm{g}$ & $<10^{2} \mathrm{CFU} / \mathrm{g}$ & $<10^{2} \mathrm{CFU} / \mathrm{g}$ \\
& Salmonella & $\mathrm{ND}$ & $\mathrm{ND}$ & $\mathrm{ND}$ \\
$\mathrm{NA}$ & Coliforms at $45^{\circ} \mathrm{C}$ & $<10^{2} \mathrm{CFU} / \mathrm{g}$ & $<10^{2} \mathrm{CFU} / \mathrm{g}$ & $<10^{2} \mathrm{CFU} / \mathrm{g}$ \\
& SA & $\mathrm{ND}$ & $\mathrm{ND}$ & $\mathrm{ND}$ \\
& Colmonella & $<10^{2} \mathrm{CFU} / \mathrm{g}$ & $<10^{2} \mathrm{CFU} / \mathrm{g}$ & $<10^{2} \mathrm{CFU} / \mathrm{g}$ \\
\hline
\end{tabular}

${ }^{1}$ TP: transparent polyethylene; PA: polyethylene coated by aluminum foil; LA: laminated foil. ND: not detected 


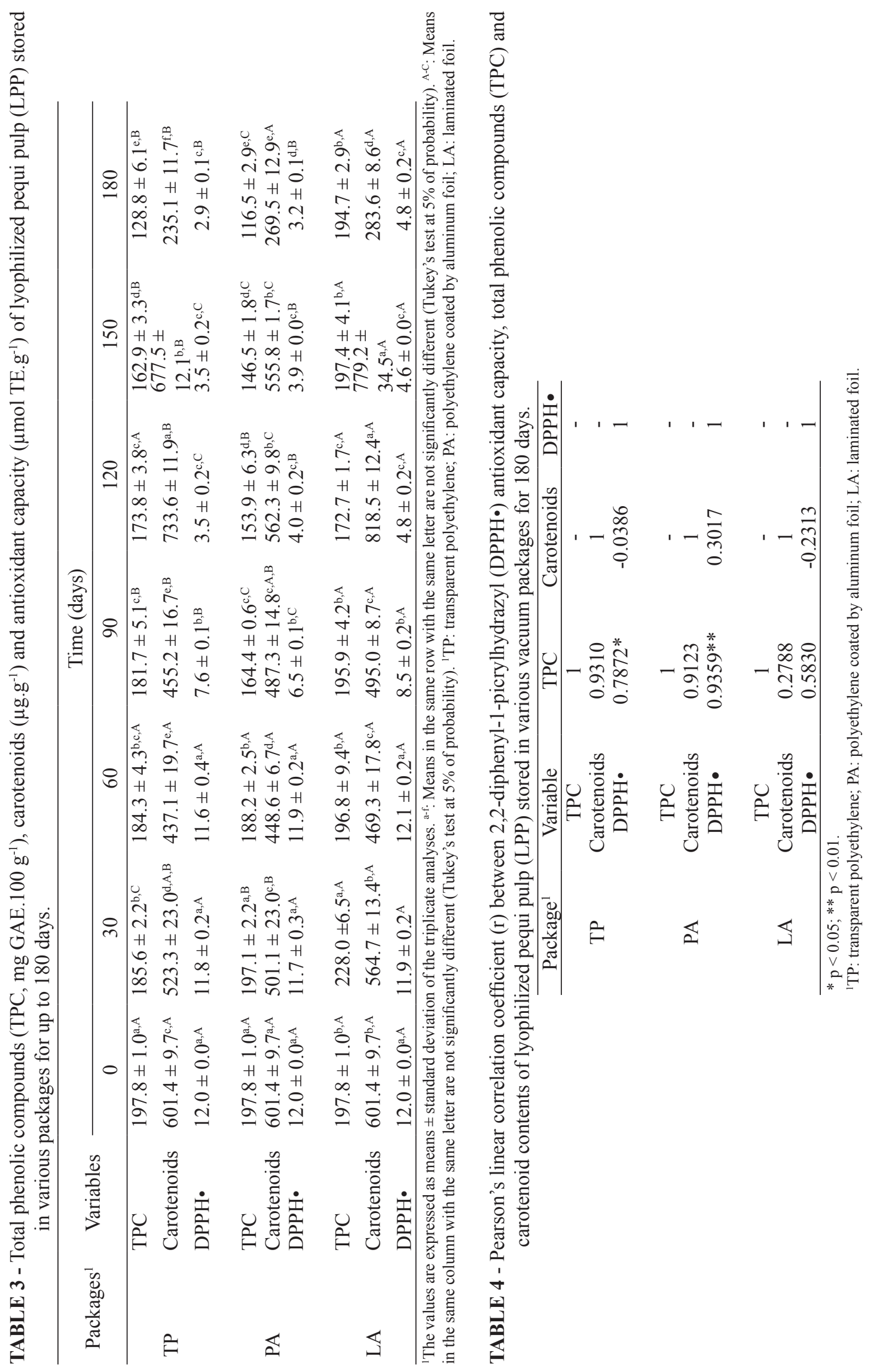



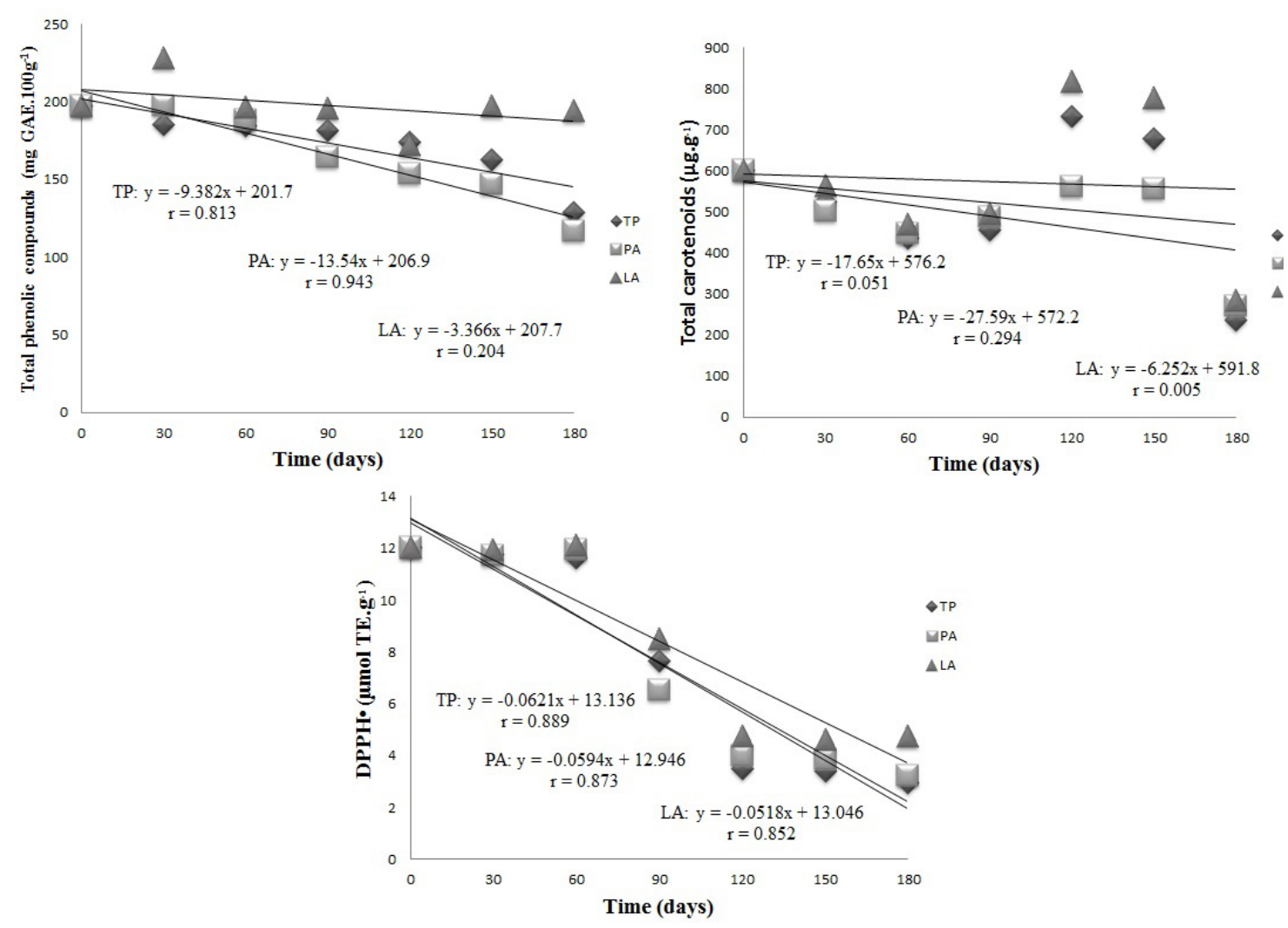

FIGURE 1 - Pearson's correlation for total phenolic compounds, carotenoid content and antioxidant capacity of lyophilized pequi pulp (LPP) stored in various vacuum packages for up to 180 days.

GAE: gallic acid equivalent; DPPH: 2,2-Diphenyl-1-picrylhydrazyl; TP: transparent polyethylene; PA: polyethylene coated by aluminum foil; LA: laminated foil.

\section{CONCLUSION}

Lyophilized pequi pulp is rich in lipids, carotenoids and phenolic compounds, and has a high $\mathrm{DPPH} \bullet$ antioxidant capacity.

Among the packages tested, the LA package is more effective at preserving the phenolic compounds and antioxidant capacity of freeze-dried pequi pulp. The light-resistant packages (PA and LA) are effective at protecting carotenoid oxidation.

There is a strong negative correlation between the total phenolic compounds and storage period, and between antioxidant capacity and storage period, and a positive correlation between antioxidant capacity and total phenolic compounds. There is no correlation between carotenoid content and storage period or antioxidant capacity.

The consumption of vacuum packaged freeze-dried pequi pulp is recommended up to 60 days of storage when the bioactive compounds and antioxidant capacity are preserved, regardless of the package used in storage.

\section{ACKNOWLEDGEMENTS}

The National Council for Scientific and Technological Development (CNPq) for financial support.

\section{REFERENCES}

APHA- AMERICAN PUBLIC HEALTH ASSOCIATION. Compedium of methods for the microbiological examination for foods. Washington, DC: APHA, 2001.

AOAC - ASSOCIATION OF OFFICIAL ANALYTICAL CHEMISTS. Official methods of analysis. 19 ${ }^{\text {th }} \mathrm{ed}$. Washington: AOAC, 2010. 
ARÉVALO-PINEDO, A.; MACIEL, V. B. B.; CARVALHO, K. M.; COELHO, A. F. S.; GIRALDOZUÑIGA, A. D.; ARÉVALO, Z. D. S.; ALVIM, T. C. Processamento e estudo da estabilidade de pasta de pequi (Caryocar brasiliense). Ciência e Tecnologia de Alimentos, Campinas, v.30, n.3, p.664-668, 2010.

BLIGH, E.G.; DYER, W.J. A rapid method of total lipid extraction and purification. Canadian Journal of Biochemistry and Physiology, Ottawa, v.37, n.1, p.911-917, 1959.

BRAND-WILLIAMS, W.; CUVELIER, M.E.; BERSET, C. Use of a free radical method to evaluate antioxidant activity. LWT- Food Science and Technology, London, v.28, n.1, p.25-30, 1995.

BRASIL. Agência Nacional de Vigilância Sanitária. Resolução RDC n ${ }^{\circ} 12$, de 02 de janeiro de 2001. Regulamento técnico sobre padrões microbiológicos para alimentos. Diário Oficial da República Federativa do Brasil, Brasília, DF, 2001.

COLOMBO, N.B.R.; RANGEL, M.P.; MARTINS, V.; HAGE, N.; GELAIN, D.P.; BARBEIRO, D.F.; GRISOLIA, C.K.; PARRA, E.R.; CAPELOZZI, V.L. Caryocar brasiliense Camb protects against genomic and oxidative damage in urethane-induced lung carcinogenesis. Brazilian Journal of Medical and Biological Research, Ribeirão Preto, v.48, n.9, p.852-862, 2015.

CORDEIRO, M.W.S.; CAVALLIERI, A.L.F.; FERRI, P.H.; NAVES, M.M.V. Características físicas, composição químico-nutricional e dos óleos essenciais da polpa de Caryocar brasiliense nativo do Estado de Mato Grosso. Revista Brasileira de Fruticultura, Jaboticabal, v.35, n.4, p.1127-1139, 2013.

FIGUEIREDO, P.R.L.; OLIVEIRA, I.B.; SANTANA NETO, J.B.; OLIVEIRA, J.A.; RIBEIRO, L.B.; VIANA, G.S.B.; ROCHA, T.M.; LEAL, L.K.A.M.; KERNTOPF, M.R.; FELIPE, C.F.B.; COUTINHO, H.D.M.; MENEZES, I.R.A. Caryocar coriaceum Wittm. (Pequi) fixed oil presents hypolipemic and antiinflammatory effects in vivo and in vitro. Journal of Ethnopharmacology, Limerick, v.191, p.87-94, 2016.

GENOVESE, M.I.; PINTO, M.S.; GONÇALVES, A.E.S.S.; LAJOLO, F.M. Bioactive compounds and antioxidant activity of exotic fruits and commercial frozen pulps from Brazil. Food Science and Technology International, London, v.14, n.3, p.207214, 2008.
HYMAVATHI, T.V.; KHADER, V. Carotene, ascorbic acid and sugar content of vacuum dehydrated ripe mango powders stored in flexible packaging material. Journal of Food Composition and Analysis, San Diego, v.18, n.1, p.181-192, 2005.

KLOPOTEK, Y.; OTTO, K.; BOHM, V. Processing strawberries to different products alters contents of vitamin $\mathrm{C}$, total phenolics, total anthocyanins, and antioxidant capacity. Journal of Agricultural and Food Chemistry, Washington, v.53, n.14, p.56405646, 2005.

LEONTOWICZ, H.; LEONTOWICZ, M.; GORINSTEIN, S.; MARTIN-BELLOSO, O.; TRAKHTENBERG, S. Apple peels and pulp as a source of bioactive compounds and their influence on digestibility and lipid profile in normal and atherogenic rats. Medycyna Weterynaryjna, Warszawa, v.63, n.11, p.1434-1436, 2007.

MCGUIRE, R.G. Reporting of objective color measurements. HortScience, Alexandria, v.27, n.12, p.1254-1255, 1992.

MENEZES, E.M.S.; TORRES, A.T.; SRUR, A.U.S. Valor nutricional da polpa de açaí (Euterpe oleracea Mart) liofilizada. Acta Amazônica, Manaus, v.38, n.2, p.311-316, 2008.

MERRIL, A.L.; WATT, B.K. Energy value of food: basis and derivation. Washington: United States Departament of Agriculture, 1973. 105 p.

MOKRANI, A.; KRISA, S.; CLUZET, S.; COSTA, G.; TEMSAMANI, H.; RENOUF, E.; MÉRILLON, J.M.; MADANI, K.; MESNIL, M.; MONVOISIN, A.; RICHARD, T. Phenolic contents and bioactive potential of peach fruit extracts. Food Chemistry, Barking, v.202, n.1, p.212-220, 2016.

NUNES, J.C.; LAGO, M.G.; CASTELO-BRANCO, V.N.; OLIVEIRA, F.R.; TORRES, A.G.; PERRONE, D.; MONTEIRO, M. Effect of drying method on volatile compounds, phenolic profile and antioxidant capacity of guava powders. Food Chemistry, Barking, v.197, p.881-890, 2016.

OLIVEIRA, D.S.; MATA, G.M.S.; LUCIA, C.M.D.; CAMPOS, F.M.; RIBEIRO, S.M.R; PINHEIROSANT'ANA, H.M. Influência da embalagem e estocagem no conteúdo de betacaroteno e ácido ascórbico em suco de manga "Ubá" industrializado. Acta Scientiarum, Maringá, v.32, n.2, p.191-198, 2010. 
OLIVEIRA, S.M.; BRANDÃO, T.R.S.; SILVA, C.L.M. Influence of drying processes and pretreatments on nutritional and bioactive characteristics of dried vegetables: a review. Food Engineering Reviews, New York, v.8, n.2, p.134-163, 2016.

OLIVEIRA, V.S.; AFONSO, M.R.A.; COSTA, J.M.C. Caracterização físico-química e comportamento higroscópico de sapoti liofilizado. Revista Ciência Agronômica, Fortaleza, v.42, n.2, p.342-348, 2011.

OLIVEIRA, V.S.; COSTA, J.M.C.; AFONSO, M.R.A. Caracterização e comportamento higroscópico do pó da polpa de cajá liofilizada. Revista Brasileira de Engenharia Agrícola e Ambiental, Campina Grande, v.18, n.10, p.1059-1064, 2014.

PAZ, J.G.; PACHECO, P.; SILVA, C.O.; PASCOAL, G.B. Análise da composição nutricional e de parâmetros físico-químicos do pequi (Caryocar brasiliense Camb.) in natura. Linkania, Uberlândia, v.1, n.5, p.73-86, 2014.

PINTO, L.C.L.; MORAIS, L.M.O.; GUIMARÃES, A.Q.; ALMADA, E.D.; BARBOSA, P.M.; DRUMOND, M.A. Traditional knowledge and uses of the Caryocar brasiliense Cambess.(Pequi) by "quilombolas" of Minas Gerais, Brazil: subsidies for sustainable management. Brazilian Journal of Biology, São Paulo, v.76, n.2, p.511-519, 2016.

PRIOR, R.L.; HOANG, H.; GU, L.; WU, X.; BACCHIOCCA, M.; HOWARD, L.; HAMPSCHWOODILL, M.; HUANG, D.; OU, B.; JACOB, R. Assays for hydrophilic and lipophilic antioxidant capacity (oxygen radical absorbance capacity $\left(\mathrm{ORAC}_{\mathrm{FL}}\right)$ ) of plasma and other biological and food samples. Journal of Agricultural and Food Chemistry, Easton, v.51, n.1, p.3273-3279, 2003.

RIBEIRO, D.M.; FERNANDES, D.C.; ALVES, A.M.; NAVES, M.M.V. Carotenoids are related to the colour and lipid content of the pequi (Caryocar brasiliense Camb.) pulp from the Brazilian Savanna. Food Science and Technology, Campinas, v.34, n.3, p.507-512, 2014.
RODRIGUES, L.J.; VILAS-BOAS, E.V.B.; PAULA, N.R.F.; ALCÂNTARA, E.M. Caracterização do desenvolvimento de pequi (Caryocar brasiliense) temporão do sul de Minas Gerais. Pesquisa Agropecuária Tropical, Goiânia, v.39, n.3, p.260265, 2009.

RODRIGUEZ-AMAYA, D.B. A guide to carotenoid analysis in foods. Washington: International Life Sciences Institute, 2001. 64 p.

SELANI, M.M.;BIANCHINI,A.; RATNAYAKE, W.S.; FLORES, R.A.; MASSARIOLI, A.P.; ALENCAR, S.M.; BRAZACA, S.G.C. Physicochemical, functional and antioxidant properties of tropical fruits co-products. Plant Foods for Human Nutrition, Dordrecht, v.71, n.2, p.137-144, 2016.

SELCUK, N.; ERKAN, M. Changes in phenolic compounds and antioxidant activity of sour-sweet pomegranates cv. 'Hicaznar' during long-term storage under modified atmosphere packaging. Postharvest Biology and Technology, Amsterdam, v.109, n.1, p.30-39, 2015.

SOGI, D.S.; SIDDIQ, M.; DOLAN, K.D. Total phenolics, carotenoids and antioxidant properties of Tommy Atkin mango cubes as affected by drying techniques. LWT - Food Science and Technology, London, v.62, n.1, p.564-568, 2015.

XI, W.; ZHANG, Y.; SUN, Y; SHEN, Y.; YE, X.; ZHOU, Z. Phenolic composition of Chinese wild mandarin (Citrus reticulata Balnco.) pulps and their antioxidant properties. Industrial Crops and Products, Amsterdam, v.52, n.1, p.466-474, 2014. 